\title{
МОВНА ОРГАНІЗАЦІЯ ВНУТРІШНЬОГО ПОРТРЕТА ЛЮДИНИ (НА МАТЕРІАЛІ ЩОДЕННИКА М. ГАЛАБУРДИ-ЧИГРИН)
}

\author{
ІРИНА СИРКО \\ Дрогобицький державний педагогічний університет імені Івана Франка, \\ Дрогобич - Україна
}

JEZZYKOWA ORGANIZACJA WEWNĘTRZNEGO PORTRETU CZŁOWIEKA (NA MATERIALE DZIENNIKA M. HAŁABURDY-CZYHRYN)

IRYNA SYRKO

Państwowy Uniwersytet Pedagogiczny imienia Iwana Franki w Drohobyczu, Drohobycz - Ukraina

STRESZCZENIE. W artykule zaprezentowane zostały osobliwości autorskiego semantycznego i aksjologiczno-wartościującego formowania portretu psychologicznego człowieka w dyskursie dziennika M. Hałaburdy-Czyhryn. W funkcji konkretyzatorów stanu psychiczno-emocjonalnego nakreślona została tekstowotwórcza produktywność nominacji serce, dusza, oczy. Przeanalizowano funkcjonalność nominacji w odniesieniu do oznaczania stanu przeżywania, odczuć (samotność, spokój, ból). Zaakcentowana została również aktualność patriotyzmu jako naznaczonej etnicznie i kulturowo dominanty w procesie portretowania postaci.

\section{LANGUAGE ORGANIZATION OF THE INNER PORTRAIT OF A PERSON (BASED ON M. HALABURDA-CHYGRYN'S DIARY)}

\section{IRYNA SYRKO}

Drohobych State Ivan Franko Pedagogical University, Drohobych — Ukraine

ABSRACT. The article deals with the author's semantic and axiological-evaluative modeling of a psychological portrait of a person in the diary discourse of M. HalaburdaChygryn. The text-building productivity of such nominations as heart, soul, eyes in the function of concretizers of the person's mental-and-emotional condition has been traced. Functionality of the nominations of emotions and feelings (loneliness, peace of mind, pain) has been analysed. The actuality of patriotism as a dominant trait of portraying the characters has been accentuated.

\footnotetext{
$\mathrm{A}$ ктуальна для сучасних мовознавчих досліджень антропоцентрична парадигма дає змогу оцінювати й інтерпретувати численні факти суспільного, мистецько-культурного, когнітивного характеру з погляду людської діяльності, реалізації креативних та пізнавальних можливостей людини. Адже сьогодні „немає необхідності доводити, що концепт „людина” — ключовий концепт кожної культури. Без аналізу його змісту неможливий адекватний опис культури: місце будь-якої реалії в системі культурних цінностей незалежно від того, чи належить ця реалія рукотворному чи нерукотворному світові, -
} 
може бути визначене тільки через ту роль, яку відіграє стосовно цієї реалії людина"

Зазнаючи певних смислово-емоційних переакцентувань в контексті часу, літературної течії чи естетичної платформи, людина залишається стрижневим, базовим компонентом мовно-ментальної системи творів різних жанрів. У дослідженнях В. Русанівського, С. Срмоленко, Н. Сологуб, Л. Ставицької, Л. Кравець, Н. Дужик, М. Братусь, Л. Науменко, О. Сенькович, Г. Дядченко та ін. здійснено різноаспектний розгляд механізмів моделювання образу людини в мові української художньої прози та поезії. На матеріалі мови щоденників ця проблема комплексно поки що не висвітлена, однак достатньо продуктивне іiі розроблення в проекції на актуальні аспекти діаріумології репрезентовано в працях Т. Космеди, Л. Мацько, Т. Радзієвської, М. Степаненка. Водночас варто акцентувати потребу розгляду цієї проблеми на матеріалі щоденників, створених у діаспорі. Адже відомо, що впродовж XX ст. ціла плеяда видатних українських діячів науки, культури, освіти, політики з різних причин змушені були емігрувати з України. Крім того, сьогодні маємо уже сформоване покоління діячів, які народилися й виросли в діаспорі, але демонструють чітке й послідовне визнання своєї української ідентичності. До них, зокрема, належить і Марія Галабурда-Чигрин — журналістка, громадсько-політична діячка української діаспори Австралії, постійний кореспондент української газети „Вільна Думка” в Сіднеї, редактор і диктор Австралійського Державного радіо Сі Бі Ес, голова його українського відділу. У іiі громадській, культурно-просвітницькій діяльності, а також у достатньо об'ємних за обсягом щоденникових записах послідовно простежується типово український спосіб мовомислення і мововираження. 3 цього погляду щоденник М. Галабурди-Чигрин $є$ цінним не тільки як новітній матеріал дослідження, але і як площина реалізації образу людини.

Параметри портретування людини в мові аналізованого щоденника визначає передусім соціально-психологічне спрямування й тематика записів, які стали авторською реакцією на бурхливі суспільно-політичні події, що відбувалися в Україні в кінці 80-х — на початку 90-х років XX ст. Власне в цьому ракурсі здебільшого зображується й людина як соціальна істота, яка живе, діє, мислить у своєму часі, у цих умовах, співіснує з іншими людьми, реагує на довкілля певними психоемоційними виявами.

Отже, виокремлення мікротеми „внутрішній (психологічний) портрет” у лексико-семантичному полі „Людина”, мотивоване двома чинниками: а) стилістичною значущістю словесного опису морально-етичних цінностей, душевних станів персонажів та б) актуальною саме для текстів щоденника як egoтекстів потребою соціального й індивідуального, поведінкового портретування осіб, зображуваних й оцінюваних із різних (авторських та опосередкованих) поглядів.

Мета статті - визначити особливості семантичного й аксіологічного моделювання психологічного портрета людини в щоденникових записах М. Галабурди-Чигрин.

У мовостилі авторки основою для опису внутрішнього (психологічного) портрета людини слугує традиційний словник, який М. Галабурди-Чигирин активно збагачує індивідуальними описово-оцінними номінаціями та висловами.

До традиційних ключових одиниць психологічного портретування належать номінації серизе, душа, очі. За спостереженням Л. Ставицької, „душа і сер-

${ }^{1}$ Р. И. Розина, Человек и личность в языке, [в:] Логический анализ языка. Культурные конųепmы, Москва 1991, с. 55. 
цุе володіли певною мовно-естетичною самоцінністю в тексті з огляду на кордоцентризм національної художньої свідомості; наявність відповідних лексем уводила в царину багатогранного емоційного світу людини (...). Епітет, дієслівна метафора, традиційні порівняльні звороти — це той арсенал художніх засобів, що передають палітру духовно-емоційного життя"2. У щоденникових записах М. Галабурди-Чигрин образи серие та душа найчастіше використовуються в усталених, стереотипізованих висловах, формульних словосполуках, а також розвивають нові напрямки лексико-семантичної сполучуваності, набувають оказіональних значеннєвих відтінків. Цьому сприяє поєднання прямого й переносного значень, коли символічний зміст лексеми реалізується одночасно з їі конкретним значенням.

Слово серие є метонімічним компонентом внутрішнього мікросвіту людини, іiі емоційним центром. Це „символ зосередження почуттів, настроїв, переживань і т. ін.". Багатство його смислової реалізації в текстах щоденника, значущість у моделюванні внутрішнього портрета людини пов’ язана з емоційністю авторки-українки, оскільки „специфічними рисами української світогляднофілософської ментальності є спрямованість на внутрішній емоційно-почуттєвий світ людини, в якому панує не холодний раціональний розрахунок „голови”, але жагучий поклик „серця"4.

Мовообраз серце в записах М. Галабурди-Чигрин традиційно конкретизується в сполуках із дієсловами та віддієслівними іменниками зі значенням емоційного переживання. Загальний метафоричний зміст таких образів - „хвилюватися, тривожитися": люблю осінні квіти, щзо дихають холодом, від якого мемить серце (с. 133)5; Коли літак торкнувся вільної української землі, серце дивно защеміло (с. 132); Невиразні світечка села чогось приспішували биття мого серця (с. 38); Хотілося притулитися до землі й слухати трепету власного схвильованого серця (с. 32). В останній ілюстрації ідіостильову інтерпретацію дистрибута серце підтримує його усталена сполучуваність із прикметником схвильоване. У мовно-стилістичній системі М. Галабурда-Чигрин це означення має статус концептуальної характеристики, оскільки актуалізує знакову, визначальну для іiі ідіостилю сему 'схвильованість'.

Образ серие в записах М. Галабурди-Чигрин вербалізує широкий спектр чуттєво-інтимних переживань людини, найвиразнішим і найсильнішим із яких $є$ почуття прихильності, любові: Відразу зрозуміла, щзо Карпати припадуть мені до серця, і то на все моє життя (с. 104); Я закохана в Україну всією душею, всім серцем (с. 130).

Т. Космеда слушно наголошує на тому, що „мовна особистість елітарного типу з високим рівнем комунікативної компетенції, вміє (...) відповідними способами „викидати” негативні емоції, позбавлятися їх за допомогою відповідних дій, зокрема й мовленнєвих" теристика свого психоемоційного стану словами із семою 'вогонь', порівн.: Якби изе говорив українецьь, я би цуе терпіла, а то чужинець. Я не витримала. Вибухну-

2 Л. О. Став ицька, Естетика слова в украӥнській поезії 10-30 pp. ХХ ст., Київ 2000, с. 77.

${ }^{3}$ Словник української мови, в 11 тт., Київ 1978, т. 9, с. 141-142.

${ }^{4}$ I. В. Бичко, Ментальна співзвучність украӥнської та європейської філософської традииій: „,Кордоцентричні мотиви”, [в:] Київські обрії: історико-філософські нариси, Київ 1997, с. 325.

${ }^{5}$ М. Галабурда-Чигрин, Україно, моя Україно... (Щоденник), Київ 2000. *Далі в дужках указуємо сторінки за цим виданням.

${ }^{6}$ T. А. Косм еда, Ego i Alter Ego Tapaca Шевченка в комунікативному просторі щоденникового дискурсу, Дрогобич 2012, с. 50. 
$л \boldsymbol{a}$ (с. 163). Образ вогню як маркер інтенсивного вияву почуттів часто виступає внутрішньоконтекстним контактером лексеми серие: залишили ви в моєму серці незгасимий вогонь почувань! (с. 116). На думку О. Селіванової, така „аналогізація психоемоційного стану зі стихією вогню $є$ популярним когнітивним процесом людської свідомості, що відбивається в мові”7.

На увагу заслуговують епізодичні вживання похідних від іменника серие прислівника сердечно та прикметника сердечний (добрий, чулий (про людину та іiі вдачу) $)^{8}$. Це актуальні вербалізатори щирості вияву почуттів: Коли я cniвала цю пісню..., тоді не думала, що слова їі чи не найповніше й найсердечніше висловлюють любов і шану кожного, хто хоч раз відвідав столицю нашої Батьківщиини (с. 21); Побачивщи мене, сердечно привітався (с. 135); Там стояла вся родина Бандери..., які були раді мене знов бачити й які сердечно віталися зі мною й ,моїми хлопиями” (с. 77); Пан Федір - людина сердечна, жартун (с. 174).

Частотними в записах діаристки є метафори 3 ключовим словом серие, в яких цей образ виступає активною, дієвою реалією, центром переживань, напр.: Ти же вмієш говорити від серця, навіщо читала шаблонний привіт? (c. 93); Якась тепла хвиля припливла до серця (с. 38); Ох, як хоче моє серце знов тебе зустріми (с. 163).

Досліджуючи параметри емоційної компетенції людини, Т. Космеда зазначає: „Специфічною ознакою системності під час категоризації емоцій $є$ їх бівалентність, тобто позитивні й негативні емоції можуть оволодіти людиною одночасно". В аналізованих текстах засвідчено приклади, що акцентують увагу на оксиморонному поєднанні в образі серия протилежних почуттів - суму й радості, порівн.: Відчула, що навіть весела пісня чомусь смутком серце mисне (с. 172). Вказівка на синтез кількох почуттів у межах однієї образної конструкції мотивує повноту, інтенсивність вияву переживань авторки.

Щоденник М. Галабурди-Чигрин за всіма ознаками належить до так званого белетризованого типу. За спостереженням А. Ільків, такий тип щоденникових записів репрезентує тяглість традиції філософії серия, проте символ серце наповнюється новим змістом: він виходить за межі антропологічної філософії серця, його кордоцентризм наділений новою рисою - двоиентричністю: символи серие й душа досягають єдності ${ }^{10}$. Обидва названі образи розкривають глибину внутрішнього світу авторки, пов'язані з демонстрацією широкого спектру приємних, оптимістичних почуттів, вражень від iї „побуту” в Україні: Тому, що я не поетеса - попробую описати Київ словами з душі, з серця (с. 21); Той ивіт вабив моє око, бентежив душу, серце! (с. 80); Я закохана в Україну всією душею, всім серцем (с. 130). Отже, метафоризація серия в записах М. Галабурди-Чигрин співзвучна з метафоризацією номінації душа, що часто детермінує їх контекстне ототожнення.

Текстотвірний потенціал номінації серце розкривається завдяки багатству зв'язків, якими вона поєднується з іншими елементами тексту. Адже лексикосемантична природа слова дозволяє йому „входити в змінні контексти, внаслідок чого змінюється й смислове наповнення слова, що повертається різними

${ }^{7}$ О. О. Селіванова, Нариси з украӥнської фразеології (психокогнітивний та етнокультурний аспекти), Київ — Черкаси 2004, с. 117.

${ }^{8}$ Словник української мови: в 11 тт., Київ 1978, т. 9, с. 131.

9 Т. А. Космеда, Зазнач. прачя, с. 51.

${ }^{10}$ А. В. Ільків, Жанр щзоденника в украӥнській літературі другої половини ХХ - початку XXI століть: автореф. дис. канд. філол. наук, Івано-Франківськ 2008, с. 9. 
боками"11. Про це свідчить метафора з оригінальним індивідуально-авторським осмисленням серия: Мені здається, щзо я принесла Украӥні через океан своє серце - а зберігаю тут ії серце (с. 130).

Смислово-оцінну розбудову образу серце як центру емоційних переживань засвідчують також уведені в контекст експресеми туга, ностальгія тощо: Три тополі на три сторони - / Три струни в моїм серці натужсено, / Три шляхи у моєї весни — / Та не знаю, який мені суджено!... / Мерехтять в далині три дороги, / У якому краю я шукатиму — / Долю свою? (с. 11).

Номінація душа (,внутрішній психічний світ людини, з ії настроями, переживаннями та почуттями"12) на сторінках щоденника виступає одним із ключових елементом окреслення внутрішнього портрета людини. Реалізуючи образний потенціал в епітетних, метафоричних структурах, ця номінація стає стрижнем численних експресивно маркованих контекстів: Не могла вже так (з природи бунтівну) душу заспокоїти (с. 99); Вже було темно, як ми верталися в Коломию з враженням і зболеною душею з відвідин Яблунівських криниць (с. 111). Сумовиту „настроєність” останнього запису підсилює словосполука Яблунівські криниці (місце, де в 1990 році проведено розкопки жертв НКВД).

Входячи до складу настроєвих рядів епітетів, концептуальне слово душа не тільки розширює межі традиційної лексичної сполучуваності, а й відображає особливості національної картини світу. Показовим із цього погляду є контекст, у якому національні нашарування в оцінці внутрішнього стану персонажа вербалізує прикметник українська: Зрушила, збудила я його, як він казав, украӥнську душу (с. 111). Компонентом креативної індивідуальності тут виступає метафора зрушити, збудити душу.

Епізодично репрезентована в щоденнику ідентифікаційна метафора тиша душа, порівн.: Тиша - душа перед боєм (с. 124). Така модель належить до традиційних, але малопродуктивних у слов’янській лінгвокультурі, як і інші „інтелектуальні” або „етичні” тлумачення душі ${ }^{13}$.

Багатоетапність індивідуальних переосмислень номінації душа зумовлює народження контекстів, побудованих на конкретно-чуттєвих асоціаціях, що мають відповідну лексичну реалізацію в різнотипних за граматичним оформленням метафоричних конструкціях. Коли в дуиі виростає... Київ із золотими верхами над хвилястими вулицями.., мені хочеться співати і співати (с. 99); І хоч до мене всі всміхалися, хоч всі говорили, я і тоді не могла позбутися отого поняття, яке осіло на дні душі - „моя присутність тут небажана”(с. 133). Динамічність вияву почуттів та емоцій часто пов'язана $з$ дієслівною метафоризацією лексеми душа: Родимий краю, села родимі, вас я вітаю, місия любимі! Вас привітати душа бажсає - більшої втіхи в світі немає! (с. 93); Я ̈̈хала в Украӥну, щзоби полюбити ї̈ всією душею (с. 59). Наведені рядки ментально співзвучні з думкою О. Забужко про те, що для представників діаспори „Україна - країна дитинства і водночас потойбічного, позасвітного блаженства, тобто країна, де душа „у себе вдома"

Особливої семантичної об'ємності набуває аналізований образ у дієслівних метафорах, що аргументують природу духовної впливовості слова,

${ }^{11}$ Н. А. Кожевникова, Словоупотребление в русской поэзии начала $X X$ века, Москва 1986, c. 241.

12 Словник української мови, в 11 тт., Київ 1971, т. 2, с. 445.

13 С. М. Толстая, Славянские мифологические представления о душе, [в:] Славянский и балканский фольклор. Народная демонология, Москва 2000, с. 55.

${ }^{14}$ О. Забужко, Шевченків міф Украйни. Спроба філософського аналізу, Київ 2001, с. 113. 
спогаду: Його слова збентежили мою душу (с. 141); Спогади про пережите за тих кілька тижнів бентежать душу (с. 129). Стан збентеження, хвилювання описують метафори, в яких лексема душа поєднується з носіями семи 'вогонь', порівн.: В моїи душі запекла якась нова сила, що народжуеться від невідомих почувань (с. 108); На поверхню душі повернулося оте поняття, яке пекло в грудях від перших днів мого побуту в Києві (с. 173).

В інтерпретації російської дослідниці С. Толстої душа осмислена як умістище духовної субстанції (духу): „у неї є глибина, дно, тайники, закутки”.15. Опредметнення абстракції душа у вказаних параметрах уможливлює ії „вимір” у традиційних та індивідуальних метафорах просторової семантики: Не знаю, чи стрінемося знову! Та спомини про зустріч з вами ховаю на дно своєї душі! (c. 116); Були хвилини, які зворушували мене до самої глибини душі (с. 59); На поверхню душі повернулося оте поняття, яке пекло в грудях від перших днів мого побуту в Києві (с. 173).

Орієнтація на передавання, переконливе відтворення психоемоційних станів людини (переживання, хвилювання, страху) простежується за параметрами зображення такої деталі портрета, як очі. Посилена увага авторки до цього аспекту портретування не випадкова. 3 одного боку, це наслідок зануреності М. Галабурди-Чигрин у національну словесну культуру, типово український спосіб мововираження. 3 іншого боку, ця тенденція має психолінгвальну мотивацію, оскільки зумовлена також тим, що „очі найкраще передають характер і настрій людини, оскільки є зоровим центром тіла, а зіниці не підлягають контролю свідомості”" лексико-семантичного сегменту „зовнішній портрет людини” (в такому ракурсі відповідна номінація в щоденнику М. Галабурди-Чигрин уживається найчастіше), однак ціла низка слововживань цього іменника стосується опису саме внутрішнього світу, психологічного стану людини. Найбільш функціонально навантаженим у цій стилістичній площині виявляється епітетна характеристика колючі: А оті колючі очі ніби насміхалися з мене, немов питались ,щңо ти, дура, хочеш?" (с. 121); Його колючі очі звузилися, на почервонілім обличчі з'явився вираз жорстокості (с. 121). Експресивно маркований епітет колючі поєднується 3 конкретизувальними зовнішньопортретними характеристиками (напр., почервоніле обличчя) - на цій підставі констатуємо створення цілісного ситуативного портрета персонажа.

В епітетну парадигму дистрибута очі входить також означення иікаві, що акцентує психологічний стан людини, а не зовнішньопортретну рису: Цікаві очі немов запитували - „хто це такий їе?’” (с. 101).

Силу, інтенсивність погляду передають сполуки очі + іменник із семою 'вогонь'. Мотиваційною основою метафоричних проекцій такого типу стали уявлення про здатність очей випромінювати світло, що, на думку О. Селіванової, $€$ „експресивним позначенням психоемоційних, рідше фізіологічних станів людини залежно від конотації дієслів чи спектра знаків вогню, світла"17. Аналогізацію очей зі стихією вогню засвідчують щоденникові рядки В очах світилися жсиві іскорки, не тільки свідчення молодості, але й впевненості в свойй правоті (с. 68). Динамічність наведеної характеристики, що ііі забезпечує дієслово зі смисломоделювальною семою 'вогонь' (світилися) та іменник іскорки,

\footnotetext{
${ }^{15}$ С. Толстая, Зазнач. праия, с. 54-55.

${ }^{16}$ Л. Кравець, Динаміка метафори в украӥнській поезї XX ст., Київ 2012, с. 222-223.

${ }^{17}$ О. О. Селіванова, Зазнач. прачя, с. 95.
} 
творить єдине семантичне ціле з експресивністю епітетної характеристики живі. В комплексі вони формують місткий психологічний портрет емоційно збудженого персонажа, окреслений через зовнішньопортретну деталь очі.

У віршованих рядках запису від 1 листопада 1990 р. засвідчуємо асоціацію очей із водною стихією. В основі такої лінгвокогнітивної проекції Л. Кравець вбачає архетипну модель вода - світло: „Якщо, за давніми уявленнями, очі випромінюють світло, то воно може ототожнюватися 3 водою"18. Асоціація за подібністю очей з озерами є основою розгорнутої й асоціативно ускладненої метафори: Я в твоїх очах, Україно, втопився (с. 98).

Складна гама людських почуттів декодується в асоціативно ускладненій авторській метафорі із стрижневим компонентом очі: А очі кричали, а очі стогнали... А очі мовчали, вони вже щцссь знали. І просто дивились...Молились... (c. 130). Метафори такого типу профілюють силу почуттів та емоцій, їхню стихійність, спонтанність, непідвладність розуму.

Метафоричні сполуки очі оптиміста / песиміста умотивовують позитивний / негативний ракурс сприймання довкілля, порівн.: погляд на суспільнополітичне життя в Україні залежить від того, очима якої людини дивитися: оптиміста чи песиміста. Якщзо дивитися з точки зору песиміста, то дійсно, в Україні відчуття небезпеки висить в повітрі...Попереду прогнозоване безробіття. Та незважаючи на те все, я намагаюся вдивлятися в майбутнс Украӥни очима оптиміста (с. 62).

Як вербалізатор широкого спектра значень лексема очі входить до складу описових метафоричних конструкцій зі значенням „дивуватися, сумніватися”, „3'ясовувати": А Богдан Нагайло, який сидів на балконі, не вірив свойм очам і потім спитався мене... (с. 56); Ця друга моя подорожс по Україні дещзо більше відкрила мені очі на реальну дійсність там (с. 97).

Отже, на сторінках щоденникових записів М. Галабурди-Чигрин вибудовується цілісна лексико-семантична система психологічного портретування людини, стрижневе місце в якій належить традиційним номінаціям серце, душа, очі. Вони виформовують контекстуальні ряди епітетних, метафоричних, метонімічних характеристик із різним типом оцінності, конкретизують описи психоемоційного стану персонажів.

Значний сегмент у парадигмі зображення внутрішнього стану людини формують лексеми на позначення певних настроїв, переживань, відчуттів. Найбільш стилістично нейтральна в цьому корпусі лексема спокій - „стан душевної рівноваги, відсутність хвилювань, сумнівів, клопотів та ін." ${ }^{19}$. В описах стану спокою авторка використовує закріплені в національномовній практиці засоби: предикативні означення бути заспокоєним, бути спокійним (Дещуо заспокосна пішла спати (с. 166); Ти вернешся, бо, здається, будеш спокійною лише тодi, коли будеш з Батьківщиною (с. 175); Люблю приготовитись, вибрати відповідні пісні, бути душевно „,спокійною”...(с. 109-110); Питання - чи була би спокійною, коли б прийтлося щзодня вистоювати в них [чергах - I. C.] за харчами (с. 90), обставини (Мені здавалося, щзо після побаченого в Україні я не зможу спокійно жити на чужині (с. 62); Люди дивувалися, щуо я з Австралї̈ й спокійно стою в черзі! (с. 90), предикати односкладних речень (Хотіла вернутися туди, де смереки шепочуться з вітрами, так, в Карпати, на Верховину! Там все просто. Спокійно й прекрасно (с. 121).

\footnotetext{
${ }^{18}$ Л. Кравець,Зазнач. праия, с. 226.

${ }^{19}$ Словник української мови, в 11 тт., Київ 1978, т. 9, с. 560.
} 
Як стверджує К. Танчин, „неспокій, ... прояснений словом, видається не таким серйозним, не так пригнічує; слово допомагає оволодіти своїм станом"20. Таку думку переконливо підтверджують вислови із щоденника: Телефонічні розмови дещзо мене вспокойли (с. 174); Хлопці вспокоювали ї̈, щзо ніхто Леніна не чіпатиме (с. 88).

Психологічний стан заспокоєння часто описано з опертям на семантику однойменних дієслівних лексем: В Сінгапурі я дещзо вспокоїлася (с. 177); Це мене дещзо вспокоӥло (с. 58).

Власну мікропарадигму розвиває в щоденнику М. Галабурди-Чигирин антонімічна кореляція до слова спокій - лексема неспокій як назва психологічного стану, пов'язаного з негативними переживаннями: надворі холодно. Закрадався неспокій. Де ділися Іван та Геннадій? (с. 166). Значне функціональне навантаження в описах пригніченого стану людини мають епітетні та дієслівні характеристики неспокійний, не заспокоїтися (в значенні хвилюватися): Люди там ... знервовані дикими обставинами життя. Їх жстття неспокійне (с. 176); Я не могла заспокойтися. Не знала навіть, чого переживала (с. 176).

Самодостатню лексико-семантичну мікросистему в загальній моделі психоемоційного портретування людини формує лексема самотність. На сторінках аналізованого щоденника це домінантна характеристика безпорадної, екзистенційно невлаштованої людини: Ми залишилися самі на порожній платформі (с. 164); І врешті - я сама. В кімнаті стало тихо-тихо (с. 171); Крислаті каштани шуміли своӥм лапатим листям. Десь загриміло. Мені було лячно самій в невеликій квартирі (с. 139).

Нетрадиційний стилістичний ракурс реалізації мотиву самотності людини в навколишньому світі пов'язаний із концептуальним оновленням закоріненої в народній словесності міфологічно мотивованої метафоричної макромоделі людина - природа. Адже „народнопісенна ситуація часто вибудовується на зіставленні настрою природи і людини"21. Але якщо народна поезія через об'єктивацію паралелізму окреслює стан психологічної гармонії людини 3 довкіллям, то М. Галабурда-Чигрин передусім акцентує іiї значно тісніший психологічний зв'язок зі світом природи, аніж зі світом людей: Та хіба я сама? У вікно місяць зазирає, зорі мерехтять...(с. 138).

Двоспрямовану оцінність, аксіологічну неоднозначність образу самотнос$m i$ у сприйнятті М. Галабурди-Чигрин засвідчують іï авторські самохарактеристики, в яких цей стан маркується як психологічно обтяжливий, негативний (Цей останній вечір я не можу провести на самоті (с. 174) або ж, навпаки, внутрішньо необхідний, бажаний (Мені не хотілося з ніким говорити. Потрібно було побути на самоті, віч-на-віч з собою. Хотіла попрощатися з Украйною (с. 58).

Негативний ракурс стану самотності акцентують дієслівні метафори iз загальним значенням ,самотність пригнічує”: А ота самітність мене догризала. Сотні разів ставила собі питання: чого че я сама в чотирьох стінах невеличкої чужсї квартири? (с. 138). Проілюстрований опис психологічного стану авторки увиразнює характеристика обмеженого простору іiі перебування - чотири стіни невеличкої чужої квартири.

Часто вживані в щоденнику М. Галабурди-Чигрин абстрактні іменники самотність, самота здебільшого виконують роль оцінок чи самооцінок

${ }^{20}$ К. Танчин, Щоденник як форма самовираження письменника: автореф. дис. канд. філол. наук, Тернопіль 2005, с. 8.

${ }^{21}$ С. Срмоленко, Фольклор і літературна мова, Київ 1987, с. 112. 
і смислово заступають цілі розгорнуті описи: Порівняла цеей вечір до самітнього вечора в день мого приїду (с. 174).

Сема 'самотність' визначає зміст описових метафоричних конструкцій, у яких немає формальних лексичних носіїв відповідної семантики, однак вона імпліцитно закладена у внутрішній формі тексту, порівн.: Мені хотілося кричати на весь Київ... Та люди десь поспішали. Таксівка одна за другою від ’̈жджала. Хто б мене слухав? (с. 15).

Для експресивного увиразнення образу самотності як психоемоційного стану людини продуктивний також прийом внутрішньотекстового контрастування: море квітів, рукотиснення багатьох людей, обійми, сльози, інтерв'ю... Й раптом я опинилася сама на непривітному, холодному московському летовищі! (с. 59); Як иеей мій приїзд відрізнявся від попередніх. Були вони гучними, зустрічали мене гуртом, відбувалися вітальні обіди чи вечері, а тут я раптом сама в чужій квартирі! (с. 133). Базову семантику предикативної характеристики сама ефективно підсилюють негативно марковані словосполуки непривітне, холодне московське летовище; чужа квартира тощо.

Частотний компонент моделювання портрета людини в щоденнику М. Галабурди-Чигирин - лексема біль. Здебільшого іiі вжито в номінативній функції, в прямому, кодифікованому в загальномовних словниках значенні „відчуття фізичного страждання"22, порівн.: В мене страшенний біль в криюжах (с. 157); Відчула гострий біль у грудях (с. 121). За таких умов поняття біль стає елементом опису ситуативного фізичного стану людини.

Інтерпретація образу біль як маркера психологічного стану людини пов'язана із зображенням відчуття прикрості, образи, смутку: Такі мої думки котилися хвилями. Пробували змити біль розлуки з Украӥною (с. 177); Після розлуки з нею настав час болю. Часами той біль був нестерпним. Я часто плакала (с. 62). Засвідчено також численні розгорнуті метафоричні конструкції з прислівниковим конкретизатором дії або інтенсифікатором оцінки боляче: Переконалася, щзо те, щзо живучи в Австралії, можу зробити для Украӥни изе так боляче мало. Хочеться зробити для неї багато більше (с. 129); тепер мені до болю важкко погодитися з тим, щзо я покинула Украӥну (с. 59); Боляче дивитися на ті черги, на вимучені личя жінок, на незадоволених мужчин (с. 176); Боляче, нестерпно боляче було приходити до изього табору (с. 68).

Імпліцитно властиву образу біль негативну оцінність розвиває епітет болісний: Відчула якусь болісну порожнечу (с. 21).

Знакова риса аналізованого щоденника, що підкреслює його соціально орієнтований характер, настанову авторки на фіксацію актуальних для українського соціуму кінця XX ст. суспільно-політичних, світоглядних проблем, це акцентування такої риси характеру українців, як патріотизм. У конкретних контекстах для показу ставлення персонажів до своєї країни, народу авторка використовує традиційні лексичні засоби. Насамперед це дієслово люблю в поєднанні 3 власною назвою Украӥна, іменниками батьківщзина, земля, а також асоціативно й тематично пов'язані з ними поняття (поля, простори, ріки, гори) тощо: Мені хотілося від украӥнців в Україні, а тим самим від Украӥни, не одного, як хочеться від коханої істоти. Та люблю їі такою, якою вона $\epsilon$, тому, щзо вона наша, рідна! (с.130); Земле, матінко моя, / Ялюблю Твої поля - / Я люблю твої простори, / Ріки і високі гори, / Вірним серием назавжди! (с. 99). Остання ілюстрація є пісенним епіграфом до запису від 3 травня 1991 р.,

\footnotetext{
${ }^{22}$ Словник украӥнської мови, в 11 тт., Київ 1970, т. 1, с. 186.
} 
що в тексті виконує функцію апеляції до мовно-культурної пам'яті - і національної, й індивідуально-авторської.

На семантичному контрасті до наведених вибудувані описи непатріотичних учинків згаданих у щоденникових записах тих чи тих осіб: Між нами $\epsilon$ людина, яка задля свого власного жсивота зрадила інтереси народу (с. 69); Багатьох хоче виїхати на Захід (с. 176); Коли в їх кишенях завелися доляри, вони повернулися обличчям до батьківщини лище з одною метою - заробити там швидко (с. 177); Там [в Україні - I. С.] саме зараз можна використати дешево оплачувану роботу й швидко доробитися! Так роблять ті, які повернулися до свого украӥнства тепер, коли стало „модним” ӥзити в Украӥну (c. 177). Зауважимо, що в інтерпретації М. Галабурди-Чигрин книжний іменник українство виражає іронічно-саркастичний смисл.

Наскрізним для мови аналізованого щоденника є прийом контрастування 3 акцентуванням поняття „патріотизм” в оцінці теренних та діаспорних українців: Вияснила, щзо я вперше в житті відчула, щуо таке Батьківщина, щзо цее жити міжс своїми людьми. Почуття приналежності до народу тут дуже сильне, почуття, щуо ти вдома, просто захоплює. Правда, люди, які виросли в Австралії, цього не розуміють, тому, щзо в Австралії немає поняття nampiomuзмy (с. 21). Співзвучні з наведеним численні фрагменти сприймаються як дидактично марковані міні-дискурси, націоцентричність яких виявляють вислови відданість ідеї, знання історї, віра в перемогу, праця у напрямку визволення України тощо, наприклад: Жити на чужині - це борг перед Батьківщиною, яка пробує стати на ноги (с. 21); Люди мусять знати, звідки їхнє коріння, звідки їхні предки (с. 123); Люди мусять глибоко знати навіть недавню історію (с. 123); Люди ... працюють в напрямку визволення України (с. 97), цілком віддані своӥм ідеям (с. 97); молодь бореться за права народу (с. 97); твердо вірять, що переможуть (с. 68).

Здійснене дослідження засвідчує, що опис психологічного портрета людини в мовостилі М. Галабурди-Чигрин спирається на традиційний функціональностильовий арсенал зображення персонажа з характерним лексичним наповненням, наскрізними частотними компонентами, соціологізацією зображуваного. Основу лексичного корпусу становлять базові для національного словника психологічного портретування номінації (душа, серце, очі), що в контекстах збагачуються новими описово-оцінними відтінками. Домінантними параметрами психологічного портрета виступають назви нейтральних (спокіŭ), позитивних (любов) та негативних (неспокій, самотність, біль) психоемоційних станів і почуттів персонажів, а також така знакова 3 погляду авторки риса національного характеру, як патріотизм.

Перспективу цього напряму діаріумологічних студій визначає необхідність вивчення окресленого в щоденникових записах внутрішнього портрета людини - одного з домінантних сегментів вияву мовної особистості та світогляду авторки у сфері еgо-тексту як самодостатнього сегмента національної лінгвокультури. 